\title{
Detention and Recycling Basins for Managing Nutrient and Pesticide Runoff from Nurseries
}

\author{
Salvatore S. Mangiafico, Jay Gan, Laosheng Wu, and Jianhang Lu \\ University of California, Riverside, Department of Environmental Sciences, \\ Geology Building 2208, Riverside, CA 92521
}

Julie P. Newman ${ }^{\mathbf{1}}$ and Ben Faber

University of California, Cooperative Extension, Ventura County, 669 County Square Drive, Suite 100, Ventura, CA 93003

\author{
Donald J. Merhaut \\ University of California, Riverside, Department of Botany and Plant \\ Sciences, 2150 Batchelor Hall, Riverside, CA 92521
}

\section{Richard Evans \\ University of California, Davis, Department of Plant Sciences, One Shields Avenue, Davis, CA, 95616}

Additional index words. nitrate, nitrogen, phosphorus, pesticide, pyrethroid, organophosphate, organochlorine, water use, costs

\begin{abstract}
Production nurseries may be significant sources of nutrients and pesticides in runoff as a result of the intensity at which fertilizers, pesticides, and irrigation water are applied. Concentrations of nutrients and pesticides in runoff from production nurseries are not extensively documented. Runoff from 11 production nurseries in southern California using either recycling or detention basins was monitored for nutrients and pesticides. For six sites, runoff volume was determined and nutrient loads in runoff were calculated. Water use data, percentage of water recycled, and construction costs were determined for sites with recycling systems. Nutrient concentrations, mass loads, and pesticide detections in runoff from some sites would have been of concern without the implementation of detention or recycle basins. There were few differences in nutrient concentrations or pesticide detections between runoff from irrigation and that from precipitation events. This suggests the need for management practices and technologies that address runoff from both irrigation and precipitation events. Water use and cost data suggested that the implementation of recycling systems may be more beneficial and cost-efficient for larger facilities.
\end{abstract}

Nutrient and pesticide runoff from agricultural production facilities is a concern because it is regarded as a potential nonpoint source pollution of surface waters. Nurseries may be significant sources of these constituents as a result of the intensity at which fertilizers, pesticides, and irrigation water are applied during production. Furthermore, in some cases, the use of particular pesticides may be legally required to control quarantined pests such as fire ants or may be

\footnotetext{
Received for publication 13 Sept. 2007. Accepted for publication 10 Dec. 2007.

Funding for this research was provided by the California State Water Resources Control Board in accordance with the Costa-Machado Act of 2000.

Special thanks to the cooperating nurseries, the California Cut Flower Commission, and University of California staff Kristine Gilbert, Dale Zurawski, Amy Ellis, Shahram Ahmadian, Harold Ewing, Svetlana Bondarenko, and Frederick Ernst.

${ }^{1}$ To whom reprint requests should be addressed; e-mail jpnewman@ucdavis.edu
}

necessary to produce aesthetically pleasing ornamental products. Sources of nutrients and pesticides in nursery runoff include fertilizers injected into irrigation water, leachate from containers, fertilizer, and potting media spills, and applied pesticides. The injection of fertilizers into overhead irrigation water is common in container nurseries in southern California. This practice may lead to increased nutrient runoff losses because a portion of the applied fertilizer falls outside the containers. Similarly, deposition of sprayed pesticides between pots and within aisles has been noted for containerized foliage plants (Wilson et al., 2005). These potential contaminants may move offsite in runoff produced by either irrigation or precipitation, contributing to pollution of surface water downstream.

Concentrations of nutrients and pesticides in runoff from production nurseries are not well documented. Studies simulating container production indicate that runoff or leaching losses of nutrients, particularly nitrogen, may be considerable in some sit- uations (Broschat, 1995; Colangelo and Brand, 2001; Fare et al., 1994; McAvoy, 1994; Ristvey et al., 2004; van der Boon and Niers, 1983). One survey of 29 container nurseries in the eastern United States found that nitrate-nitrogen $\left(\mathrm{NO}_{3}-\mathrm{N}\right)$ concentrations in runoff, ponds, and wells commonly exceeded the U.S. Environmental Protection Agency (EPA) maximum contaminant level (MCL) of $10 \mathrm{mg} \cdot \mathrm{L}^{-1}$, although some sites typically had low concentrations (Yeager et al., 1993).

A variety of insecticides, including organochlorine compounds, organophosphates, pyrethroids, and carbamates, is commonly found in surface waters (Schulz, 2004; Starner et al., 2006) and may exceed levels of aquatic toxicity or water quality guidelines. Agriculture is often inferred to be the source of these pesticides with runoff as the principal pathway, although other vectors such as aerial drift may be important (Schulz, 2004). Insecticides are of particular concern in surface waters because of their potential toxicity to aquatic organisms and the potential to disrupt aquatic ecology (Clark et al., 1989; Hill, 1989; Schulz, 2004). Relative to the other forms of agricultural runoff, the contribution of production nursery runoff to pesticide loading of surface waters is not well understood.

Certain pesticides, including some pyrethroids and organophosphates, have been found to be particularly associated with sediments (Bondarenko and Gan, 2004; Lu et al., 2006b; Starner et al., 2006), suggesting that practices and technologies that prevent sediment from moving offsite will be beneficial in cases where these pesticides are a concern. Other pesticides such as the carbamate carbaryl and the organophosphate diazinon may be transported primarily in the water phase of surface waters (Bondarenko and Gan, 2004). Pesticide runoff loads from production nurseries are a concern also because the persistence of some pesticides may be prolonged in nursery runoff sediments or recycling pond waters (Gan et al., 2005, Lu et al., 2006a).

A variety of cultural practices such as improved irrigation efficiency, fertilizer management, and pest management have been advocated to limit runoff losses of fertilizers and pesticides (Newman, in press). Technologies that can capture runoff water such as detention basins and recycling (retention) basins are particularly desirable for facilities where cultural practices have not been effective in preventing offsite runoff (Mathers et al., 2005). Detention basins and ponds have been shown to be effective in the reduction of runoff volumes, sediment loads, and nutrient loads in agricultural situations (Cooper and Knight, 1990; Edwards et al., 1999; Fiener et al., 2005) and urban settings (Oberts and Osgood, 1991; Sherwood, 2001). Their use in production nurseries has been advocated (Fain et al., 2000; Lu et al., in press) as has the recycling of drainage water (Merhaut, in press; Molitor, 1990; Skimina, 1986, 1992). Because many pesticides are associated with sediments and organic matter 
in runoff water, technologies that capture these constituents should be effective in reducing the off-site losses of these pesticides. However, the effectiveness of these technologies in reducing nutrient and pesticide runoff is not well documented.

This study was conducted to survey nutrient concentrations, nutrient mass loads, and pesticides in runoff from production nurseries and to evaluate the effectiveness and costs of detention basins and recycling systems in mitigating such runoff.

\section{Materials and Methods}

Site descriptions, sampling, and chemical analysis. Runoff from 11 production nurseries that use either recycling or detention basins was monitored for nutrient and pesticide concentrations. Sites were located in Ventura or Los Angeles counties in southern California. The nurseries varied in production area size, crop types (including container plants, field-grown flowers, and large containerized trees), production facilities (including greenhouse, shadehouse, and outdoor facilities), and water application methods (including microirrigation, overhead irrigation, and handwatering). Many nurseries represented a combination of crop types, production facilities, and water application methods; therefore, no attempt was made to classify sites by these attributes. Production area is listed by nursery in Table 1 .

Runoff water flowing into detention or recycling basins was collected as manual grab samples or as composites of sequential samples taken with auto samplers (American Sigma 900; Hatch Company, Loveland, CO). Samples were collected between June 2005 and Nov. 2006 with collection frequency varying by site, typically approximately once per month. Sampling duration varied from 6 to 17 months across sites with an average of $\approx 11$ months. The numbers of samples taken per site are shown in Tables 1 and 2 for nutrient and pesticide samples, respectively. Samples included runoff from both irrigation events and precipitation events. One site had no runoff from irrigation events and therefore was sampled only during precipitation events.

Samples for nutrient analysis were collected in 250-mL polyethylene bottles (Nalgene Labware; Nalge Nunc International, Rochester, NY) and samples for pesticide analysis were collected in 1-L amber glass jars (I-chem 300 series; Chase Scientific Glass, Rockwood, TN). Samples were stored at $4{ }^{\circ} \mathrm{C}$ until analysis. Samples for nutrient analysis were filtered through polycarbonate membranes with a $0.4-\mu \mathrm{m}$ pore size (Millipore, Billerica, MA). Pesticide analysis was conducted on unfiltered whole water samples, which included any pesticides associated with sediments or organic matter. Automated discrete colorimetric analysis was used to determine concentrations for $\mathrm{NO}_{3}-\mathrm{N}$ (EPA method 353.2; U.S. EPA, 1993), ammonium-nitrogen $\left(\mathrm{NH}_{4}-\mathrm{N}\right)(\mathrm{EPA}$ method 350.1; U.S. EPA, 1979), and ortho-

Table 1. Production area, number of samples, and median nutrient concentration of runoff entering detention or recycle basins for 11 production nurseries in southern California.

\begin{tabular}{llccccc}
\hline Nursery & $\begin{array}{c}\text { Basin type } \\
\text { used }\end{array}$ & $\begin{array}{c}\text { Production } \\
\text { area } \\
(\text { ha })\end{array}$ & $\begin{array}{c}\text { Number of } \\
\text { samples for } \\
\text { nutrient analysis }\end{array}$ & $\begin{array}{c}\text { Median } \\
\mathrm{NO}_{3}-\mathrm{N} \\
\left(\mathrm{mg}^{-1} \mathrm{~L}^{-1}\right)\end{array}$ & $\begin{array}{c}\text { Median } \\
\mathrm{NH}_{4}-\mathrm{N}, \\
\left(\mathrm{mg} \cdot \mathrm{L}^{-1}\right)\end{array}$ & $\begin{array}{c}\text { Median } \\
\mathrm{PO}_{4}-\mathrm{P}, \\
\left(\mathrm{mg} \cdot \mathrm{L}^{-1}\right)\end{array}$ \\
\hline $\mathrm{a}$ & Recycle & 8.10 & 4 & 24.5 & 0.29 & 1.13 \\
$\mathrm{~b}^{\mathrm{z}}$ & Recycle & 68.8 & 31 & 60.8 & 12.3 & 2.51 \\
$\mathrm{c}$ & Recycle & 6.48 & 6 & 58.1 & 12.6 & 19.4 \\
$\mathrm{~d}^{\mathrm{z}}$ & Recycle & 20.2 & 15 & 198 & 6.62 & 7.28 \\
$\mathrm{e}^{\mathrm{z}}$ & Recycle & 3.24 & 12 & 10.7 & 0.19 & 2.61 \\
$\mathrm{f}$ & Recycle & 28.7 & 1 & 5.40 & 0.65 & 0.53 \\
$\mathrm{~g}^{\mathrm{z}}$ & Recycle & 3.64 & 4 & 120 & 9.68 & 28.0 \\
$\mathrm{~h}$ & Recycle & 11.7 & 11 & 43.1 & 3.12 & 3.24 \\
$\mathrm{i}$ & Detention & 18.2 & 12 & 0.49 & 0.06 & 0.33 \\
$\mathrm{j}^{z}$ & Detention & 7.29 & 10 & 13.3 & 1.35 & 1.09 \\
$\mathrm{k}^{z}$ & Detention & 16.2 & 11 & 18.2 & 0.40 & 4.23 \\
& & Sum & 117 & & & \\
& & Overall median & & 35.6 & 3.10 & 2.69 \\
\hline
\end{tabular}

${ }^{2}$ Runoff volume and nutrient mass loads measured for this site.

Table 2. Production area, number of samples, and percent samples with detections of pesticides in runoff entering detention or recycle basins for 11 production nurseries in southern California.

\begin{tabular}{|c|c|c|c|c|c|}
\hline Nursery & $\begin{array}{l}\text { Production } \\
\text { area } \\
\text { (ha) }\end{array}$ & $\begin{array}{c}\text { Number of } \\
\text { samples for } \\
\text { pesticide analysis }\end{array}$ & $\begin{array}{l}\text { Pyrethroid } \\
\text { detections } \\
(\%)\end{array}$ & $\begin{array}{c}\text { Organophosphate } \\
\text { detections } \\
(\%)\end{array}$ & $\begin{array}{c}\text { Organochlorine } \\
\text { detections } \\
(\%)\end{array}$ \\
\hline$a$ & 8.10 & 3 & 100 & 0 & 0 \\
\hline $\mathrm{b}$ & 68.8 & 12 & 100 & 33 & 25 \\
\hline $\mathrm{c}$ & 6.48 & 6 & 17 & 0 & 0 \\
\hline d & 20.2 & 11 & 64 & 18 & 27 \\
\hline e & 3.24 & 9 & 22 & 11 & 33 \\
\hline$f$ & 28.7 & 1 & 100 & 100 & 0 \\
\hline g & 3.64 & 4 & 0 & 75 & 0 \\
\hline h & 11.7 & 5 & 100 & 40 & 20 \\
\hline i & 18.2 & 11 & 73 & 64 & 36 \\
\hline $\mathrm{j}$ & 7.29 & 6 & 50 & 83 & 67 \\
\hline \multirow[t]{3}{*}{$\mathrm{k}$} & 16.2 & 8 & 63 & 25 & 13 \\
\hline & Sum & 76 & & & \\
\hline & Total detections & & 62 & 36 & 25 \\
\hline
\end{tabular}

phosphorus $\left(\mathrm{PO}_{4}-\mathrm{P}\right)$ (EPA method 365.2; U.S. EPA, 1993). Pesticide analysis was conducted by gas chromatography with electron capture detector for four classes of pesticides: pyrethroids, organophosphates, organochlorines, and carbamates, following methods consistent with EPA methods 3510C, 8141, and 8081 (U.S. EPA, 1997).

Nutrient load determination. For six sites, runoff volume was determined by flowthrough V-notch or trapezoidal flumes, and nutrient mass loads in runoff were calculated. Those sites for which loads were calculated are indicated in Table 1. Time periods for which loads were determined varied by site, ranging in duration from 2 to 7 months, with the average duration being $\approx 5$ months. Flows were monitored continuously by measuring water depth with a pressure transducer (model WL400; Global Water Instrumentation, Gold River, CA) and recorded by a data logger (model CR10X; Campbell Scientific, Logan, UT). Water depths were then converted to flow volumes based on flume geometry. Time periods were not necessarily continuous within any one site, and the seasons for which loads were determined varied across sites. Loads were then expressed on a per-year per-hectare basis.

Water use and costs. Water use data for nurseries were collected from municipal water company records or onsite from inline water use meters for wells or recycling sys- tems. The amounts of water saved by using recycling systems were estimated by calculating the percentage of recycled water used in relation to the total water use for a period of time. Total water use was calculated as the sum of recycled water and fresh water used. A duration of 1 year was used when possible. However, in cases in which recycling basins or water use meters were recently installed, a shorter duration was used, and data were extrapolated to annual use without adjustments for seasonal differences. Water use data were collected only from those nurseries using recycling systems. Water use could be reliably estimated for five of eight sites with recycling systems (Table 3 ).

Cost data were gathered from receipts furnished by cooperators at the nursery sites and from estimates of expenses developed by cooperators. Estimates included all costs associated with completing a detention basin or recycling system, including, for example, planning, permitting, design, materials, labor, and necessary supporting activities such as grading and laying weed cloth. However, operational costs such as maintenance, energy consumption, or chemical inputs were not included. Cost data were available for six recycling systems and detention basins at two sites.

Statistical analysis. Median concentrations for $\mathrm{NO}_{3}-\mathrm{N}, \mathrm{NH}_{4}-\mathrm{N}$, and $\mathrm{PO}_{4}-\mathrm{P}$ in runoff samples were determined by site. 
Table 3. Water use for eight production nurseries using water recycling systems in southern California.

\begin{tabular}{lcccc}
\hline Nursery & $\begin{array}{c}\text { Production } \\
\text { area (ha) }\end{array}$ & $\begin{array}{c}\text { Total water use } \\
\left(10^{6} \mathrm{~L} \cdot \mathrm{ha}^{-1} \cdot \mathrm{yr}^{-1}\right)\end{array}$ & $\begin{array}{c}\text { Recycled water } \\
\left(10^{6} \mathrm{~L} \cdot \mathrm{ha}^{-1} \cdot \mathrm{yr}^{-1}\right)\end{array}$ & $\begin{array}{c}\text { Recycled } \\
\text { water (\%) }\end{array}$ \\
\hline $\mathrm{a}$ & 8.10 & 8.85 & 1.27 & 14 \\
$\mathrm{~b}$ & 68.8 & 15.4 & 6.47 & 42 \\
$\mathrm{c}$ & 6.48 & 7.61 & $\mathrm{~N} / \mathrm{A}$ & $\mathrm{N} / \mathrm{A}$ \\
$\mathrm{d}$ & 20.2 & $\mathrm{~N} / \mathrm{A}$ & $\mathrm{N} / \mathrm{A}$ & N/A \\
$\mathrm{e}$ & 3.24 & 2.79 & 0.44 & 16 \\
$\mathrm{f}$ & 28.7 & $\mathrm{~N} / \mathrm{A}$ & $\mathrm{N} / \mathrm{A}$ & N/A \\
$\mathrm{g}$ & 3.64 & 39.7 & 21.1 & 53 \\
$\mathrm{~h}$ & 11.7 & $\mathrm{~N} / \mathrm{A}$ & $\mathrm{N} / \mathrm{A}$ & N/A \\
& Median & 8.85 & 3.87 & 29 \\
\hline
\end{tabular}

$\mathrm{N} / \mathrm{A}=$ data not available.
Median values were considered the appropriate statistics for central tendency because concentration values did not follow a normal distribution. A linear regression was applied to determine if a relationship existed between median concentrations for each nutrient constituent and production area across sites. Nutrient samples were pooled across all samples for all sites and analysis of variance (ANOVA) was performed to determine the effects of event (irrigation or precipitation), basin type (detention or recycle basin), and the interaction of these effects. A natural log transformation was applied to nutrient concentrations to meet the assumption of normal distribution of residuals for ANOVA.

For sites at which runoff volume was quantified, nutrient concentrations were multiplied by corresponding discharges to determine mass loads in runoff. $\mathrm{NO}_{3}-\mathrm{N}$ and $\mathrm{NH}_{4}-\mathrm{N}$ were summed to determine mineralnitrogen (mineral-N) for ease of presentation. Median annual loads were determined across sites.

Samples for which any pyrethroid pesticide was detected were counted, and this count was divided by total samples taken for analysis of pesticides for each site. Regression analysis was used to determine if a relationship existed between the percentage of detection of pyrethroids and production area across sites. The counts of detections and nondetections were pooled across sites and a categorical linear model analysis was performed to determine the effects of event (irrigation or precipitation) and basin type (detention or recycle) and the interaction of these two effects. These analyses were repeated for the other classes of pesticides investigated. The high proportion of samples with pesticide concentrations below detection limits precluded the determination of simple statistics of central tendency of concentrations such as means or medians in some cases (U.S. EPA, 2000).

A linear regression analysis was applied to determine if a relationship existed between production area and each of per-hectare water use, per-hectare recycled water use, and percentage of water recycled. A similar analysis was performed for recycling system costs. A first-order inverse relationship $(y=a+$ $b / x)$ was determined relating per-hectare recycling system costs and production area. This is the appropriate model when a linear relationship with intercept is found between total costs and production area.

Analyses were performed in the Statistical Analysis Software (SAS) package (SAS Institute Inc., 2006) using the REG, GLM, NLIN, or CATMOD procedures. For regression and ANOVA, models were checked for homoscedasticity, normality of residuals and independence of residuals (Tabachnick and Fidell, 2001).

\section{Results and Discussion}

Nutrient concentrations and loads. Median nutrient concentrations in runoff entering recycling or detention basins varied notably across sites (Table 1 ). Median $\mathrm{NO}_{3}-\mathrm{N}$ concentration exceeded the U.S. EPA MCL of $10 \mathrm{mg} \cdot \mathrm{L}^{-1}$ for nine of 11 sites (Table 1). No significant correlation was found between median nutrient concentrations and production area $(P \geq 0.05)$. The range in nutrient concentrations in runoff samples pooled across sites was also notably large (Fig. 1). For example, the 10th and 90th percentiles for $\mathrm{NO}_{3}-\mathrm{N}$ concentrations for samples from irrigation events were 1.18 and $245 \mathrm{mg} \cdot \mathrm{L}^{-1}$, respectively. Median concentrations for $\mathrm{NO}_{3}-\mathrm{N}$ were 40.3 and $15.6 \mathrm{mg} \cdot \mathrm{L}^{-1}$ for samples from irrigation events and precipitation events, respectively (Fig. 1), indicating that more than half of the samples for either event type exceeded the U.S. EPA MCL. These observations suggest that runoff for some samples and some sites would be of concern had these sites not used mitigation practices such as detention basins or recycling systems.

No differences in mean log concentrations were found between samples taken during irrigation events and precipitation events for either $\mathrm{NO}_{3}-\mathrm{N}$ or $\mathrm{PO}_{4}-\mathrm{P}$ (Fig. 1; $P \geq 0.05)$. However, for $\mathrm{NH}_{4}-\mathrm{N}$, the mean $\log$ concentration for runoff from precipitation events was significantly lower than that for irrigation events (Fig. 1; $P=0.0042$ ). These results suggest that mitigation of runoff from both irrigation and precipitation events will be important in managing impacts of nutrient runoff to surface waters. With the Mediterranean climate of coastal southern California, where the majority of precipitation occurs between November and March, the predominant seasonal effect was expected to be expressed in the comparison of samples generated from precipitation and those from irrigation. Although the pollutant concentrations in the initial flush of precipitation runoff may be high relative to those from irrigation runoff, concentrations in
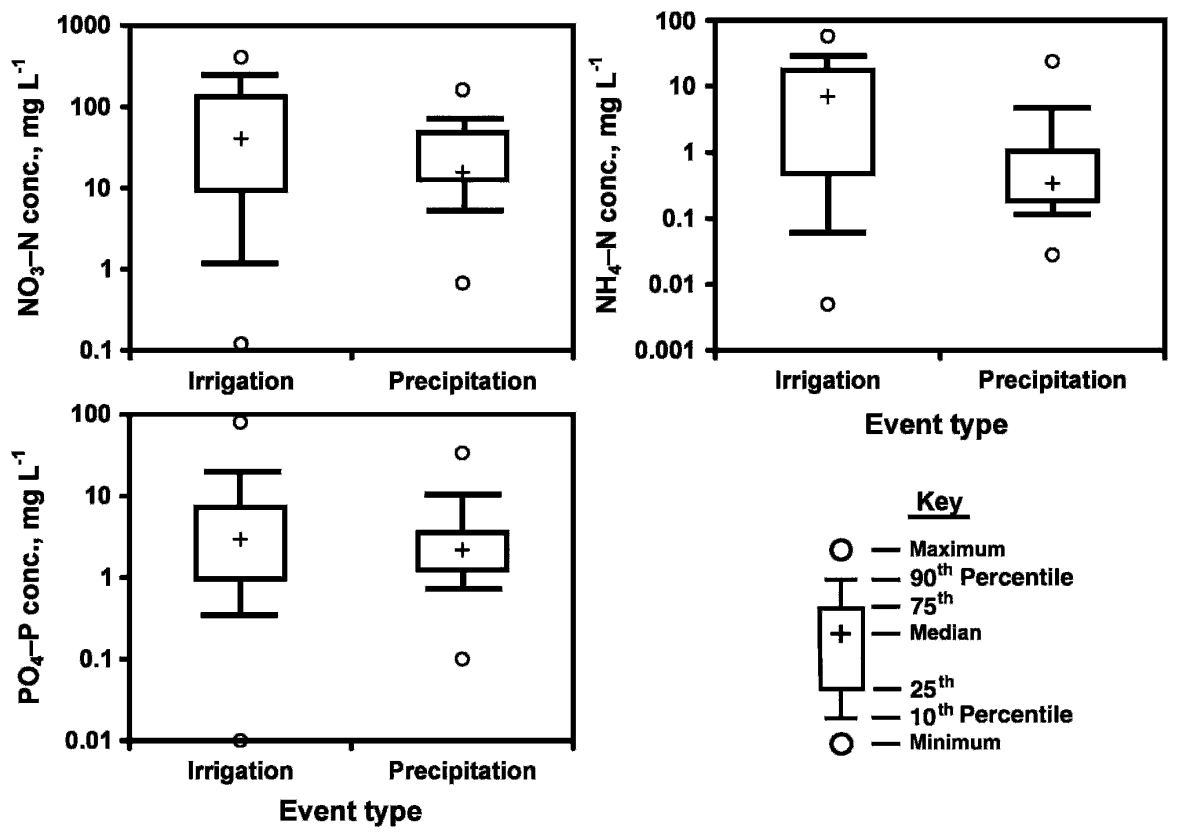

Fig. 1. Box plots of nutrient concentrations in runoff from 11 production nurseries in southern California. Runoff was collected as it entered detention or retention basins. The $y$-axes are log scale and vary among plots. Significant differences in mean $\log$ concentrations were found between event types for $\mathrm{NH}_{4}-\mathrm{N}(P=0.0042)$, but not for $\mathrm{NO}_{3}-\mathrm{N}$ or $\mathrm{PO}_{4}-\mathrm{P}(P \geq 0.05)$. Median concentrations for $\mathrm{NO}_{3}-\mathrm{N}$ were 40.3 and $15.6 \mathrm{mg} \cdot \mathrm{L}^{-1}$ for samples from irrigation events and precipitation events, respectively. Median concentrations for $\mathrm{NH}_{4}-\mathrm{N}$ were 7.03 and $0.34 \mathrm{mg} \cdot \mathrm{L}^{-1}$, and for $\mathrm{PO}_{4}-\mathrm{P}$ were 2.96 and $1.18 \mathrm{mg} \cdot \mathrm{L}^{-1}$. Total number of observations per plot is 117 . 
precipitation runoff may be lower after this initial flush as a result of dilution effects (von Broembsen, 1998).

These results for $\mathrm{NO}_{3}-\mathrm{N}$ concentrations are comparable with results for bed runoff from 29 container nurseries in the eastern United States, which ranged from 0.1 to 135 $\mathrm{mg} \cdot \mathrm{L}^{-1}$ (Yeager et al., 1993), although their reported means ( 8 and $20 \mathrm{mg} \cdot \mathrm{L}^{-1}$ ) are lower than our median values.

Nutrient loads in runoff varied considerably across sites, from 11.8 to 631 $\mathrm{kg} \cdot \mathrm{ha}^{-1} \cdot \mathrm{year}^{-1}$ for mineral-N and 1.21 to $36.5 \mathrm{~kg} \cdot \mathrm{ha}^{-1} \cdot$ year $^{-1}$ for ortho-phosphorus (ortho-P) (Fig. 2). Median nutrient loads were 40.9 and $3.64 \mathrm{~kg} \cdot \mathrm{ha}^{-1} \cdot$ year $^{-1}$ for mineral-N and ortho-P, respectively (Fig. 2). Because runoff volume was not quantified for an entire year at any one site and runoff volume is expected to vary seasonally and by precipitation events, extrapolated annual nutrient loads will be approximate. Although nutrient loads in runoff from production nurseries are not commonly reported, losses can be compared with leaching losses from experimental studies in humid climates. Nitrogen leaching losses from other experiments were comparable, although typically lower than our results: 17 to $61 \mathrm{~kg} \cdot \mathrm{ha}^{-1} \cdot$ year $^{-1}$ for outdoor Rhododendron (Colangelo and Brand, 2001), 3 to $90 \mathrm{~kg} \cdot \mathrm{ha}^{-1}$ within $150 \mathrm{~d}$ for transplanted outdoor Weigela and Campanula (Andersen and Hansen, 2000), and $\approx 40$ to $120 \mathrm{~kg} \cdot \mathrm{ha}^{-1}$ across 3 months for outdoor Rudbeckia (Bugbee and Elliot, 1998).

Pesticide detections and concentrations. The percentage of runoff samples in which pesticides were found varied across sites (Table 2). Pyrethroids were found in runoff at 10 of 11 sites (Table 2). Organophosphates and organochlorines were found at nine and seven sites, respectively. No significant correlation was found between percent of samples with pesticide detections by pesticide class and production area $(P \geq 0.05)$. Carbamate pesticides were not detected in any runoff sample.

With samples pooled across sites, pyrethroid detections were common $(63 \%$ and $58 \%$ for irrigation and precipitation events,

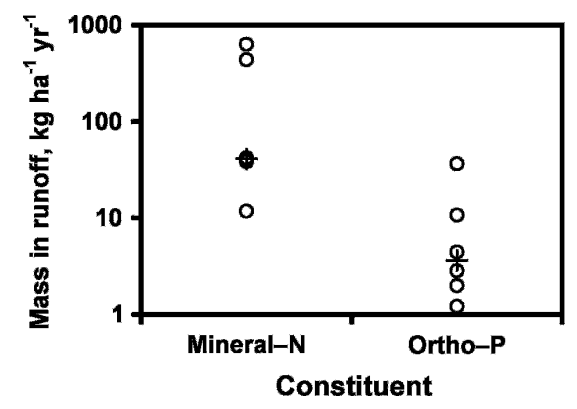

Fig. 2. Mass loads of mineral nitrogen $\left(\mathrm{NO}_{3}-\mathrm{N}\right.$ plus $\mathrm{NH}_{4}-\mathrm{N}$ ) and ortho-phosphate from 11 production nurseries in southern California. The $y$-axis is $\log$ scale. Circles represent loads from individual sites, and crosses represent the median values. Median loads were 40.9 and 3.64 $\mathrm{kg} \cdot \mathrm{ha}^{-1} \cdot \mathrm{year}^{-1}$ for mineral nitrogen and orthophosphate, respectively. respectively), whereas detections for organophosphate and organochlorine pesticides were less common $(48 \%$ and $8 \%$, and $29 \%$ and $17 \%$, respectively) (Fig. 3). No differences in the frequency of detection were found between samples taken during irrigation events and precipitation events for either pyrethroid or organochlorine pesticides (Fig. 3; $P \geq 0.05$ ). However, for organophosphate pesticides, a significant difference in detection frequency was found between irrigation events and precipitation events (Fig. 3, $P<0.0001 ; 48 \%$ and $8 \%$ for irrigation and precipitation events, respectively). Concentrations for detected pesticides are given in Table 4. These observations suggest that managing runoff from both irrigation and precipitation events would be important in mitigating potential impacts to surface water. Common detections and high concentrations of pyrethroid compounds in nursery runoff suggest that conventional insecticides such as organophosphates and carbamates are being replaced with pyrethroid products. This is a concern because pyrethroids typically have high acute aquatic toxicities (Clark et al., 1989; Hill, 1989).

Detection frequencies for pyrethroids were similar to those found by a survey of surface waters in agriculture watersheds in California, which reported detections in $61 \%$ of samples, although these were mostly in sediments and not whole water (Starner et al., 2006). Similarly, pyrethroids and organochlorine pesticides were commonly detected in sediments of surface waters and tailwater ponds in an agricultural region of California (Weston et al., 2004). However, a
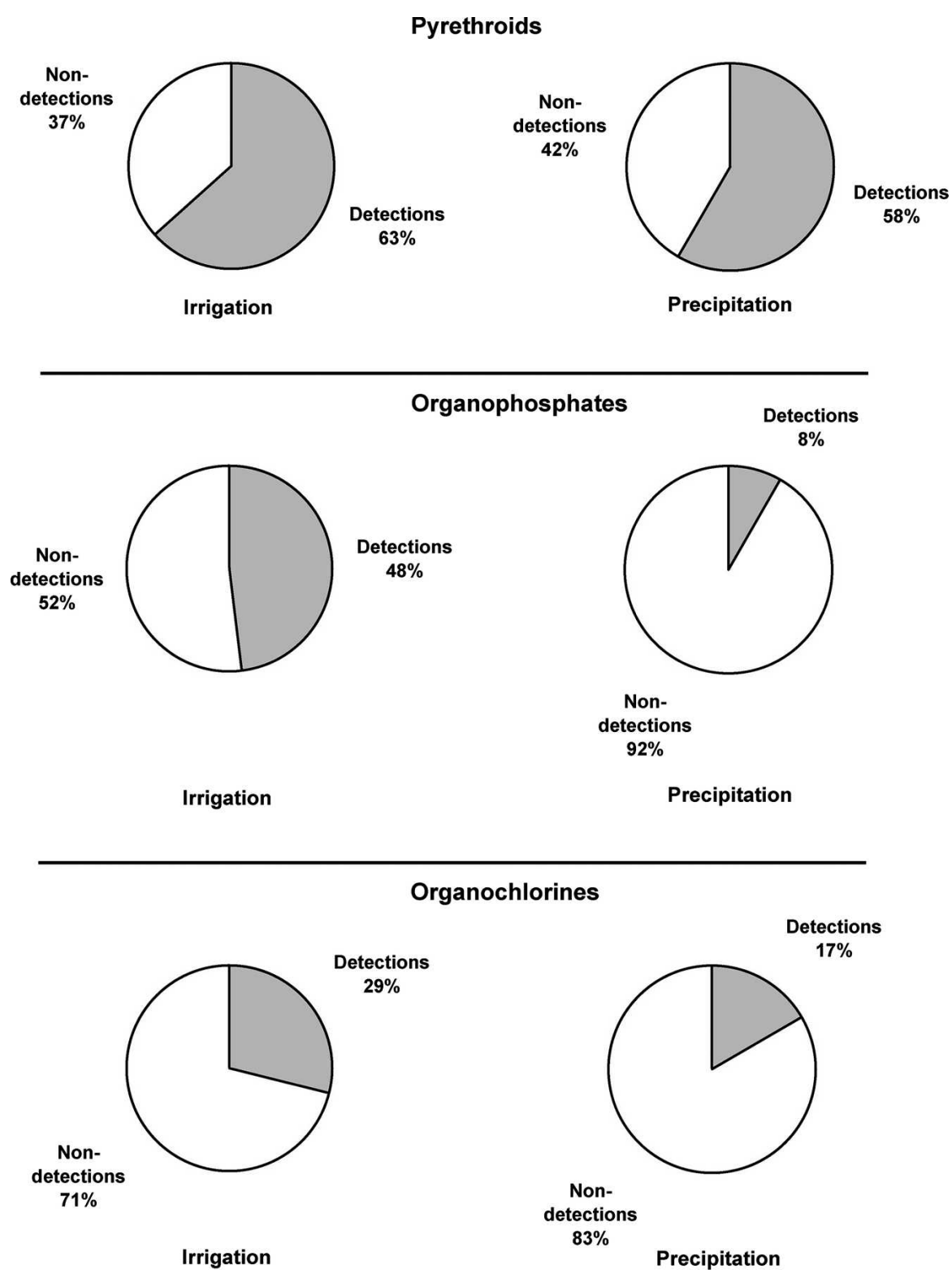

Fig. 3. Percent of samples with detections and nondetections for three classes of pesticides in runoff for 11 production nurseries in southern California. Runoff was collected as it entered detention or retention basins. A significant difference in detection frequency was found between event types for organophosphate pesticides $(P<0.0001)$, but no significant differences were found for pyrethroid or organochlorine pesticides $(P \geq 0.05)$. Total samples for each pesticide class $=76$. 


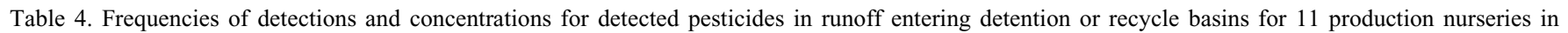
southern California.

\begin{tabular}{|c|c|c|c|c|c|c|c|}
\hline & $\begin{array}{c}\text { Number of } \\
\text { samples }\end{array}$ & $\begin{array}{l}\text { Number of } \\
\text { detections }\end{array}$ & $\begin{array}{c}\text { Detection } \\
\text { frequency }(\%)\end{array}$ & $\begin{array}{l}\text { 50th percentile } \\
\left(\mathrm{ng} \cdot \mathrm{L}^{-1}\right)\end{array}$ & $\begin{array}{c}\text { 75th percentile } \\
\left(\mathrm{ng} \cdot \mathrm{L}^{-1}\right)\end{array}$ & $\begin{array}{l}\text { 90th percentile } \\
\left(\mathrm{ng} \cdot \mathrm{L}^{-1}\right)\end{array}$ & $\begin{array}{l}\text { 100th percentile } \\
\left(\mathrm{ng} \cdot \mathrm{L}^{-1}\right)\end{array}$ \\
\hline \multicolumn{8}{|l|}{ Pyrethroids } \\
\hline Bifenthrin & 76 & 31 & 41 & $\mathrm{~N} / \mathrm{D}^{\mathrm{z}}$ & 31 & 235 & 20,063 \\
\hline Fenpropathrin & 76 & 25 & 33 & N/D & 29 & 223 & 1,267 \\
\hline cis-Permethrin & 76 & 20 & 26 & N/D & 3 & 89 & 1,061 \\
\hline trans-Permethrin & 76 & 17 & 22 & N/D & N/D & 56 & 1,588 \\
\hline Cyhalothrin & 76 & 5 & 7 & N/D & N/D & N/D & 1,532 \\
\hline Cyfluthrin & 76 & 9 & 12 & $\mathrm{~N} / \mathrm{D}$ & N/D & 5 & 889 \\
\hline Cypermethrin & 76 & 1 & 1 & N/D & N/D & N/D & 2 \\
\hline Esfenvalerate & 76 & 3 & 4 & N/D & N/D & $\mathrm{N} / \mathrm{D}$ & 396 \\
\hline Deltamethrin & 76 & 5 & 7 & N/D & N/D & N/D & 68 \\
\hline \multicolumn{8}{|l|}{ Organophosphates } \\
\hline Diazinon & 76 & 18 & 24 & $\mathrm{~N} / \mathrm{D}^{\mathrm{y}}$ & N/D & 712 & 17,416 \\
\hline Chlorpyrifos & 76 & 19 & 25 & N/D & 1 & 197 & 1,595 \\
\hline \multicolumn{8}{|l|}{ Organochlorines } \\
\hline trans-Chlordane & 76 & 8 & 11 & $\mathrm{~N} / \mathrm{D}^{\mathrm{x}}$ & N/D & 1 & 29 \\
\hline Endosulfan sulfate & 76 & 5 & 7 & $\mathrm{~N} / \mathrm{D}$ & $\mathrm{N} / \mathrm{D}$ & $\mathrm{N} / \mathrm{D}$ & 67 \\
\hline$\beta$-Endosulphane & 76 & 2 & 3 & $\mathrm{~N} / \mathrm{D}$ & $\mathrm{N} / \mathrm{D}$ & $\mathrm{N} / \mathrm{D}$ & 9 \\
\hline Aldrin & 76 & 5 & 7 & N/D & $\mathrm{N} / \mathrm{D}$ & $\mathrm{N} / \mathrm{D}$ & 21 \\
\hline Heptachlor & 76 & 2 & 3 & $\mathrm{~N} / \mathrm{D}$ & $\mathrm{N} / \mathrm{D}$ & $\mathrm{N} / \mathrm{D}$ & 8 \\
\hline Dieldrin & 76 & 1 & 1 & N/D & N/D & $\mathrm{N} / \mathrm{D}$ & 20 \\
\hline$\alpha$-BCH (hexachlorocyclohexane) & 76 & 2 & & $\mathrm{~N} / \mathrm{D}$ & N/D & N/D & 5 \\
\hline$\gamma$-BCH (hexachlorocyclohexane) & 76 & 2 & 3 & N/D & N/D & N/D & 2 \\
\hline$p p^{\prime}-\mathrm{DDT}$ & 76 & 6 & 8 & $\mathrm{~N} / \mathrm{D}$ & $\mathrm{N} / \mathrm{D}$ & $\mathrm{N} / \mathrm{D}$ & 277 \\
\hline$p p^{\prime}-\mathrm{DDE}$ & 76 & 4 & 5 & N/D & N/D & N/D & 91 \\
\hline$p p^{\prime}-\mathrm{DDD}$ & 76 & 1 & 1 & N/D & $\mathrm{N} / \mathrm{D}$ & N/D & 6 \\
\hline
\end{tabular}

${ }^{2}$ Detection limits for pyrethroid pesticides varied, but were less than $10 \mathrm{ng} \cdot \mathrm{L}^{-1}$.

${ }^{y}$ Detection limits for diazinon and chlorpyrifos were 5 and $1 \mathrm{ng} \cdot \mathrm{L}^{-1}$, respectively.

${ }^{x}$ Detection limits for organochlorine pesticides varied between 1 and $5 \mathrm{ng} \cdot \mathrm{L}^{-1}$.

$\mathrm{N} / \mathrm{D}=$ not determined.

survey of streams in an agricultural area of California found infrequent detections of certain organophosphates and pyrethroids (Starner et al., 2005). For pesticides that are strongly associated with particulate matter, differences in detection frequency in these studies may partially reflect the amounts of particulates and organic matter in water samples.

Detention and recycle basin performance. There was no runoff from irrigation events observed leaving the property for these sites once detention basin and recycle projects were completed, suggesting that welldesigned basins have the potential for complete mitigation of dry-weather runoff. The ability of these basins to collect and detain runoff during storm events was not reliably assessed by this study. For some sites, few precipitation events occurred after the completion of basins and before the completion of the study. The ability of detention and retention basins to capture runoff from precipitation events will depend on the capacity of the basins relative to the size, intensity, and frequency of precipitation events. In cases for which mitigation of runoff from precipitation events is desired, proper engineering of basin capacity for expected precipitation events will be critical. Even in cases in which larger precipitation events cause basin overflow, basins may serve to slow water and settle sediments, mitigating the discharge of sediment-bound nutrients and pesticides.

Leaching losses of some constituents, particularly $\mathrm{NO}_{3}-\mathrm{N}$, may be a consideration for unlined basins, especially for sandy soils and unvegetated basins. Additionally, leaching through soils has been noted for a variety of pesticides, and even those that adsorb strongly to particulates may move by preferential flow (Flury, 1996). Leaching losses, however, were not assessed in this study.

Water use. For sites with recycling systems where water use data were available, use ranged from 2.79 to 39.7 million $\mathrm{L} \cdot \mathrm{ha}^{-1} \cdot$ year $^{-1}$ (Table 3) with a median of 8.85 million $\mathrm{L} \cdot \mathrm{ha}^{-1} \cdot \mathrm{year}^{-1}$. The highest water use was for Nursery $G$, which is a greenhouse hydroponic facility. The median percentage of water recycled was $29 \%$, which corresponded to a savings of 3.87 million $\mathrm{L} \cdot \mathrm{ha}^{-1} \cdot$ year $^{-1}$. These values are comparable to figures from a survey across three container nurseries and management practices in southern California, in which water use ranged from 1.05 to 31.4 million $\mathrm{L} \cdot \mathrm{ha}^{-1} \cdot \mathrm{year}^{-1}$ (Kabashima, 1993).

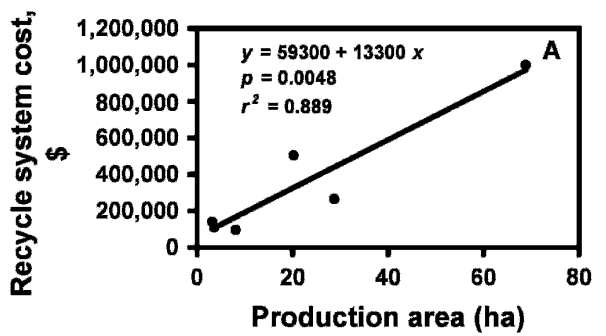

Fig. 4. Recycling system costs for six production nurseries in southern California in relation to production area. Costs were linearly related to production area $(\mathbf{A})$, and per-hectare costs were related by firstorder inverse function to production area $(\mathbf{B})$, suggesting that per-hectare costs will be greater for smaller nurseries.

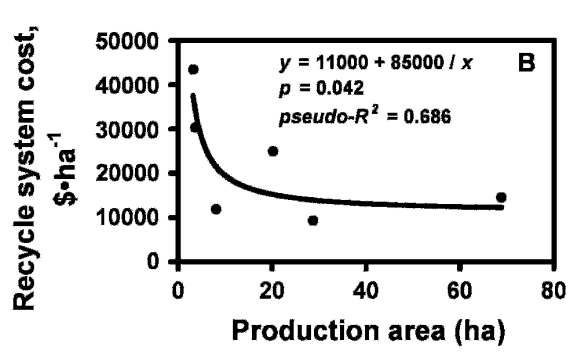

Regression analysis found no significant linear relationship between production area and any of per-hectare water use, per-hectare recycled water use, and percentage of water recycled $(P \geq 0.05)$. When data for Nursery $\mathrm{G}$, the hydroponics facility, was ignored, recycled water use on a per-hectare basis was positively linearly related to production area $\left(P=0.039, r^{2}=0.996, n=3\right)$. This relationship suggests that larger facilities may benefit more from implementing a recycling system than smaller facilities in terms of water savings.

Costs. Median costs for water recycling systems were $\$ 203,000$ with a range of $\$ 96,000$ to $\$ 1,000,000$ (Fig. 4A). Costs for recycling systems were positively linearly related to production area (Fig. $4 \mathrm{~A}, P=$ $0.0048, r^{2}=0.889, \mathrm{n}=6$ ). Median costs for recycling systems were $\$ 20,000$ per hectare with a range of $\$ 9200$ to $\$ 43,000$ per hectare (Fig. 4B), and per hectare costs were related 
by first-order inverse function to production area (Fig. 4B, $P=0.042, r^{2}=0.686, \mathrm{n}=6$ ), suggesting that larger nurseries may benefit from positive economies of scale in the installation of recycling systems. This observation is corroborated by a survey of production nurseries in Alabama, which found that runoff recycling was more common in larger nurseries (Fain et al., 2000). However, two relatively small nurseries (3.24 and 3.64 ha) in our study successfully implemented runoff recycling (Table 1). Considering detention basin construction, median costs were $\$ 31,000$ per hectare of production area (data not shown).

\section{Conclusions}

Nutrient concentrations, mass loads, and pesticide detections in runoff from some production nursery sites would have been of concern without the implementation of detention or recycle basins. These basins were successful in collecting runoff from irrigation events, but the ability of them to capture runoff from precipitation events was not assessed by this study. In general, there were few differences in nutrient concentrations or pesticide detections between runoff from irrigation and that from precipitation events. This suggests the need for management practices and technologies that address runoff from both irrigation and precipitation events. Water use and cost data suggested that the implementation of recycling systems may be more beneficial and cost-efficient for larger facilities.

\section{Literature Cited}

Andersen, L. and C.W. Hansen. 2000. Leaching of nitrogen from container plants grown under controlled fertigation regimes. J. Environ. Hort. $18: 8-12$.

Bondarenko, S. and J. Gan. 2004. Degradation and sorption of selected organophosphate and carbamate insecticides in urban stream sediments. Environ. Toxicol. Chem. 23:1809-1814.

Broschat, T.K. 1995. Nitrate, phosphate, and potassium leaching from container-grown plants fertilized by several methods. HortScience 30:74-77.

Bugbee, G.J. and G.C. Elliot. 1998. Leaching of nitrogen and phosphorus from potting media containing biosolids compost as affected by organic and clay amendments. Bull. Environ. Contam. Toxicol. 60:716-723.

Clark, J.R., L.R. Goodman, P.W. Borthwick, J.M. Patrick, Jr., G.M. Cripe, P.M. Moody, J.C. Moore, and E.M. Lores. 1989. Toxicity of pyrethroids to marine invertebrates and fish: A literature and test results with sediment-sorbed chemicals. Environ. Toxicol. Chem. 8:393-401.

Colangelo, D.J. and M.H. Brand. 2001. Nitrate leaching beneath a containerized nursery crop receiving trickle or overhead irrigation. J. Environ. Qual. 30:1564-1574.

Cooper, C.M. and S.S. Knight. 1990. Nutrient trapping efficiency of a small sediment detention basin. Agr. Water Manage. 18:149-158.

Edwards, C.L., R.D. Shannon, and A.R. Jarrett. 1999. Sedimentation basin retention efficien- cies for sediment, nitrogen, and phosphorus from simulated agricultural runoff. Trans. ASAE 42:403-409.

Fain, G.B., C.H. Gilliam, K.M. Tilt, J.W. Olive, and B. Wallace. 2000. Survey of best management practices in container production nurseries. J. Environ. Hort. 18:142-144.

Fare, D.C., C.H. Gilliam, G.J. Keever, and J.W. Olive. 1994. Cyclic irrigation reduces container leachate nitrate-nitrogen concentration. HortScience 29:1514-1517.

Fiener, P., K. Auerswald, and S. Weigand. 2005. Managing erosion and water quality in agricultural watersheds by small detention ponds. Agr. Ecosyst. Environ. 110:132-142.

Flury, M. 1996. Experimental evidence of transport of pesticides through field soils-A review. J. Environ. Qual. 25:25-45.

Gan, J., S.J. Lee, W.P. Liu, D.L. Haver, and J.N. Kabashima. 2005. Distribution and persistence of pyrethroids in runoff sediments. J. Environ. Qual. 34:836-841.

Kabashima, J.N. 1993. Innovative irrigation techniques in nursery production to reduce water usage. HortScience 28:291-293.

Hill, I. 1989. Aquatic organisms and pyrethroids. Pest. Sci. 27:429-464.

Lu, J., L. Wu, and B. Faber. Erosion and runoff management. In: Newman, J.P. (ed.). Greenhouse and nursery best management practices to protect water quality. Univ. of Calif. Div. of Agr. and Nat. Resour., Oakland, CA (in press).

Lu, J., L. Wu, J. Newman, B. Faber, and J. Gan. 2006a. Degradation of pesticides in nursery recycling pond waters. J. Agr. Food Chem. 54:2658-2663.

Lu, J., L. Wu, J. Newman, B. Faber, D.J. Merhaut, and J. Gan. 2006b. Sorption and degradation of pesticides in nursery recycling ponds. J. Environ. Qual. 35:1795-1802.

Mathers, H.M., T.H. Yeager, and L.T. Case. 2005. Improving irrigation water use in container nurseries. HortTechnology 15:8-12.

McAvoy, R. 1994. Nitrate nitrogen movement through the soil profile beneath a containerized greenhouse crop irrigated with two leaching fractions. J. Amer. Soc. Hort. Sci. 119:446451.

Merhaut, D. Water recycling in nurseries. In: Newman, J.P. (ed.). Greenhouse and nursery best management practices to protect water quality. Univ. of Calif. Div. of Agr. and Nat. Resour., Oakland, CA (in press).

Molitor, H.-D. 1990. The European perspective with emphasis on subirrigation and recirculation of water and nutrients. Acta Hort. 272:165-173.

Newman, J.P. (ed.). Greenhouse and nursery best management practices to protect water quality. Univ. of Calif. Div. of Agr. and Nat. Resour., Oakland, CA (in press).

Oberts, G.L. and R.A. Osgood. 1991. Waterquality effectiveness of a detention/wetland treatment system and its effect on an urban lake. Environ. Manage. 15:131-138.

Ristvey, A.G., J.D. Lea-Cox, and D.S. Ross. 2004. Nutrient uptake, partitioning and leaching losses from container-nursery production systems. Acta Hort. 630:321-328.

SAS Institute Inc. 2006. SAS OnlineDoc 9.1.3. Cary, NC. 25 Jan. 2008. <http://support.sas. com/onlinedoc/913/docMainpage.jsp>.

Schulz, R. 2004. Field studies on exposure, effects, and risk mitigation of aquatic nonpoint-source insecticide pollution: A review. J. Environ. Qual. 33:419-448.

Sherwood, D.A. 2001. Effects of a vegetated stormwater-detention basin on chemical quality and temperature of runoff from a small residential development in Monroe County, New York. US Geol. Surv. 25 Jan. 2008. <http://ny.water. usgs.gov/pubs/wri/wri014099/wrir01-4099.pdf>.

Skimina, C.A. 1986. Recycling irrigation runoff on container ornamentals. HortScience 21:3234.

Skimina, C.A. 1992. Recycling water, nutrients, and waste in the nursery industry. HortScience 27:968-971.

Starner, K., F. Spurlock, S. Gill, K. Goh, H. Feng, J. Hsu, P. Lee, D. Tran, and J. White. 2005. Pesticide residues in surface water from irrigation-season monitoring in the San Joaquin Valley, California, USA. Bull. Environ. Contam. Toxicol. 74:920-927.

Starner, K., J. White, F. Spurlock, and K. Kelley. 2006. Pyrethroid insecticides in California surface waters and bed sediments: Concentrations and estimated toxicities. California Department of Pesticide Regulation, Sacramento, CA. 25 Jan. 2008. <http://www.cdpr.ca. gov/docs/sw/swposters/starner_pyreth06.pdfs.

Tabachnick, B.G. and S.F. Fidell. 2001. Using multivariate statistics. 4th Edition. Allyn and Bacon, Boston, MA.

U.S. EPA. 1979. Methods for the chemical analysis of water and wastes EPA/600/4-79/020. Environmental Monitoring Laboratory, Office of Research and Development, Washington, DC.

U.S. EPA. 1993. Methods for the determination of inorganic substances in environmental samples EPA/600/R-93/100. Environmental Monitoring System Laboratory, Washington, DC.

U.S. EPA. 1997. Test methods for evaluating solid waste, physical/chemical methods. Third Edition, SW-846. Office of Solid Waste and Emergency Response, Washington, DC. 25 Jan. 2008. <http://www.epa.gov/epaoswer/hazwaste/ test/main.htm>.

U.S. EPA. 2000. Guidance for data quality assessment practical methods for data analysis EPA QA/G-9 EPA/600/R-96/084. Office of Environmental Information, Washington, DC. 25 Jan. 2008. <http://www.epa.gov/quality/ qs-docs/g9-final.pdf>.

von Broembsen, S.L. 1998. Capturing and recycling irrigation water to protect water supplies. In: Water Quality Handbook for Nurseries. Publication E-951. Univ. of Okla. Div. of Agr. Sci. and Nat. Resour., Stillwater, OK. 25 Jan. 2008. $<$ http://osuextra.okstate.edu/pdfs/e-951.pdf $>$.

van der Boon, J. and H. Niers. 1983. Leaching of nutrients from containers with nursery plants. Acta Hort. 150:227-235.

Weston, D.P., J. You, and M.J. Lydy. 2004. Distribution and toxicity of sediment-associated pesticides in agriculture-dominated water bodies of California Central Valley. Environ. Sci. Technol. 38:2752-2759.

Wilson, C., P. Strimple, S. Wilson, and J. Albano. 2005. Non-target deposition of methiocarb applied to a foliage plant staging area. Bull. Environ. Toxicol. 74:509-517.

Yeager, T., R. Wright, D. Fare, C. Gilliam, J. Johnson, T. Bilderback, and R. Zondag. 1993. Six state survey of container nursery nitrate nitrogen runoff. J. Environ. Hort. 11:206208. 